\title{
Application of Nanoscaffolds in Mesenchymal Stem Cell-Based Therapy
}

\author{
Saman Ghoraishizadeh, ${ }^{1}$ Afsoon Ghorishizadeh, ${ }^{2}$ Peyman Ghoraishizadeh, ${ }^{3}$ \\ Nasibeh Daneshvar, ${ }^{4}$ and Mohadese Hashem Boroojerdi ${ }^{5}$ \\ ${ }^{1}$ Faculty of Basic Sciences, Islamic Azad University of Mahabad, Mahabad 59136, Iran \\ ${ }^{2}$ Faculty of Basic Sciences, Islamic Azad University of Ahar, Ahar 54511, Iran \\ ${ }^{3}$ Faculty of Medicine, University of Los Andes, 762001 Santiago, Chile \\ ${ }^{4}$ Institute of Bioscience, Universiti Putra Malaysia, 43300 Serdang, Selangor, Malaysia \\ ${ }^{5}$ Faculty of Medicine and Health Sciences, Universiti Putra Malaysia, 43300 Serdang, Selangor, Malaysia
}

Correspondence should be addressed to Peyman Ghoraishizadeh; peyman.innovate@gmail.com

Received 15 May 2014; Accepted 7 September 2014; Published 23 September 2014

Academic Editor: Mahmood Khan

Copyright (C) 2014 Saman Ghoraishizadeh et al. This is an open access article distributed under the Creative Commons Attribution License, which permits unrestricted use, distribution, and reproduction in any medium, provided the original work is properly cited.

\begin{abstract}
Regenerative medicine is an alternative solution for organ transplantation. Stem cells and nanoscaffolds are two essential components in regenerative medicine. Mesenchymal stem cells (MSCs) are considered as primary adult stem cells with high proliferation capacity, wide differentiation potential, and immunosuppression properties which make them unique for regenerative medicine and cell therapy. Scaffolds are engineered nanofibers that provide suitable microenvironment for cell signalling which has a great influence on cell proliferation, differentiation, and biology. Recently, application of scaffolds and MSCs is being utilized in obtaining more homogenous population of MSCs with higher cell proliferation rate and greater differentiation potential, which are crucial factors in regenerative medicine. In this review, the definition, biology, source, characterization, and isolation of MSCs and current report of application of nanofibers in regenerative medicine in different lesions are discussed.
\end{abstract}

\section{Introduction}

Organ rupture has become a pivotal concern for population health. In the US in the year of 2010, 28,664 organs were transplanted while 110,000 more patients were still on the waiting list.

A minimum of 20 patients on the waiting list die every day before transplantation because of suitable donor shortage [1]. Organ transplantation is one of the ways to cure the patients. Because of possibility of posttransplant rejection and crucial donor shortage, scientists are now trying to find alternative ways [2].

Regenerative medicine is an alternative way which is defined as "emerging interdisciplinary field of research and clinical applications focused on the repair, replacement, or regeneration of cells, tissues, or organs to restore impaired function resulting from any cause, including congenital defects, disease, trauma, and aging" [3]. Stem cells and scaffold are the two essential components in regenerative medicine [2]. Clinical application of stem cell is the base of this field [4] that involves stem cell injection (cell therapy), activation of biological administrated molecules or cell infusion (regenerative induction), and in vitro cultured tissues or organs transplantation (tissue engineering) $[5,6]$.

Stem cells are unspecialized cell with self-renewability and potential to generate multiple mature specialized cells [13]. There are two major types of stem cells: embryonic and adult stem cells. Embryonic stem cells are isolated from the early morula stage embryos or the inner cell mass of blastocyst while adult stem cells are derived from different adult organ tissues like liver, heart, skin, teeth, bone, and so forth.

In regenerative medicine and tissue engineering, mesenchymal stem cells (MSCs) are one of the best primary adult stem cell with continual proliferation and multipotent 
differentiation potential $[14,15]$. Scaffolds are manufactured nanofibers to provide microenvironment which would ease extracellular and intracellular cell contact and signalling which influence cell proliferation, differentiation and biology $[16,17]$. Recently, the combination of MSCs and nanofibers is applied in regenerative medicine $[13,18]$.

\section{Biology of MSCs}

Mesenchymal stem cells (MSCs) were obtained for the first time by Friedenstein and Petrakova from rat bone marrow (BM). BM contains two types of stem cells: hematopoietic stem cells (HSCs) and MSCs [19]. MSCs are multipotent stem cells that are highly proliferative with the ability of selfrenewal and the potential to differentiate into various cell lines such as adipocytes, chondrocytes, osteoblasts, endothelial cells, cardiac myocytes, nerve cells, hepatocytes, and pancreatic cells [20-28]. Differentiation potential of these cells has been observed in in vivo, in vitro, and ex vivo cultures. These characteristics display various mechanisms which can contribute to the therapeutic and beneficial properties of MSCs. These cells are also referred to as BM stromal cells, BM stromal stem cells, colony-forming fibroblastic cells, and mesenchymal progenitor cells $[29,30]$. Mesenchymal tissue is an embryonic connective tissue derived from mesoderm that has the potential to differentiate into other types of connective tissue such as blood cell line; however, MSCs lack the ability to differentiate into HSCs. Stromal cells are among the connective tissue cells that form a special supportive structure in which functional cells exist. However, there is not any report to describe the potential of these cells in rehabilitation of tissue damages in regenerative medicine [31, 32].

In terms of morphology, MSCs look like unrestricted somatic stem cells (USSC): small spindle shaped cells, with large round nuclei and explicit nucleolus, some intracellular organelles, and long and short cellular projections. A substantial number of these cells in BM are surrounded by a matrix containing reticular filaments $[33,34]$. BM is one of the most important sources to isolate MSCs. However, due to lack of an appropriate method to inhibit growth of other cells in primary culture and passages, isolation and purification of MSCs from BM and obtaining a homogenous population of these cells are difficult $[35,36]$. Thus, finding alternative sources for MSCs isolation is necessary.

Recently, amniotic fluid was mentioned in literature as a significant alternative source for MSCs. In some studies, isolation of MSCs was conducted from human amniotic fluid in the second trimester of pregnancy and from C57BL/6 mice amniotic fluid $[37,38]$. Other attempts to isolate MSCs from umbilical cord blood (UCB) and peripheral blood (PB) have been carried out with paradoxical results. Some studies reported lack of MSCs in UCB [39, 40], while others have reported their existence in UCB and in umbilical cord vessels' endothelial wall (Table 1) [41, 42]. In one study, mice amniotic fluid MSCs were isolated and compared to MSCs of BM in terms of their differentiation potential. Results showed that both have high potential to differentiate into osteoblasts and chondrocytes; however, MSCs of amniotic fluid lacked the adipogenic potential. This finding showed that adipocytes are present in adult BM while they do not exist during embryonic period and also there is a direct relativity between increasing adipogenesis and aging [38, 43]. Nevertheless, another study demonstrated positive adipogenic potential

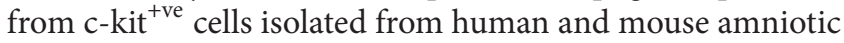
fluid by immunoselection against a stem cell receptor protein, c-kit [38]. These cells were then described as amniotic fluid stem cells rather than amniotic fluid mesenchymal stem cells. It is observed that amniotic fluid MSCs are less differentiated than bone marrow MSCs and have shorter doubling time. These features have drawn more attention in lab research [23].

\section{MSCs Immunophenotyping}

Identification of MSC specific surface markers is necessary for characterization of these cells, but certain markers have yet to be identified. Some studies introduce markers like Vcam-1, Thyl-2, and Sca-1 as common surface markers of hematopoietic, nonhematopoietic, and epithelial cells and mature T lymphocytes $[30,44]$. Another study reports lack of CD45, CD11b, and c-kit expression as isolation markers for mouse bone marrow MSCs $[45,46]$. In separate studies, STRO- $1^{\text {+ve }}$ cells were introduced as a homogenous population of cells with high junction and proliferation potential $[47,48]$.

However, differences between STRO- $1^{\text {+ve }}$ cells and MSCs are not yet clear. Also, surface markers such as CD29, CD44, CD73, CD90, CD105, CD166, and MHC class I are reported as well-known mesenchymal markers. Desirable as it is, application of one specific antibody profile against surface markers for isolation and purification of MSCs from other cell populations is not yet possible [49]. In two recent studies, neural gangliosides GD-2 and SSEA-4 are reported as surface markers of MSCs [50, 51].

\section{Isolation and Purification of MSCs}

Isolation of MSCs from BM can be carried out by different protocols such as using cytotoxic materials in culture medium, cell sorting, culture in DMEM medium with high or low density, and positive or negative selection [27, 45, 90]. The basis of these methods relies on the physical tendency of MSCs to attach to plastic surface of cell culture plate. However, these methods produce different lines of hematopoietic cells attached on the stromal layer and together they proliferated with MSCs. As a result, a heterogeneous population of cells formed on the plate. Consequently, in some of these protocols, non-MSC cells are removed from the bottom of the plate, however, leading to reduction in proliferation and differentiation potential of MSCs $[91,92]$. In another study a population of unattached MSCs in BM is reported in which a simple and effective method was used to isolate MSCs, after some modifications in culture medium and reducing trypsin treatment time, a purified population of these cells was produced after the first passage [31]. In another study, 
an unattached population of MSC is reported in BM which cannot be isolated by methods based on cell attachment [93].

\section{Nanofibers and Cell Scaffolds}

Most novel protocols of BM-MSC culture are based on isolation of mononuclear cells (MNCs), transferring of cells into cell culture medium, and their attachment to plastic surface of cell culture flask bottom [94-97]. Scaffolds are fabricated nanofibers that provide suitable microenvironment for cell signalling which would influence cell proliferation, differentiation and biology. Recently, designing biocompatible cellular scaffolds is a trend in regenerative medicine and tissue engineering. The aim of designing different scaffolds is to simulate the best structural and environmental pattern for extracellular matrix [22]. Different types of scaffolds like hybrid porous and biodegradable scaffolds based on chitosan-gelatin-triphosphate calcium, porous ceramic, and biphasic scaffold of hydroxyl apatite/tricalcium phosphate (HA/TCP) have been used for attachment, proliferation, and differentiation of MSCs into different tissues for application in tissue engineering and regenerative medicine $[97,98]$.

The MSCs can be also isolated from the adipose tissue or bone of a patient, grow in vitro, and be transferred, utilizing an applicable scaffold, onto the defected ocular surface [99]. In the other study, the critical role of mechanotransduction in the regulation of MSC fibrochondrogenesis has been investigated utilizing biomimetic nanofibrous scaffolds [100]. Scientists also investigated the feasibility of osteogenic differentiation of hUC-MSCs via application of nHA/CS/PLGA scaffolds [101].

The application of electrospinning method, which is an easy and cost effective method for designing 3D nanofiber cell scaffolds, has drawn a lot attention in tissue engineering. In this process, degradable biopolymers are used to produce nanofibers. Designed scaffold provides a matrix with pores of less than 10 microns in diameter. This matrix prevents cells from easy transit through empty spaces and provides proper conditions for attachment, proliferation, and growth of MSCs $[102,103]$. Biodegradable nanofiber scaffold based on $\varepsilon$-caprolactone (PCL) and poly-L-lactic acid (PLLA) has been used in different studies. In general, cell scaffolds are used in two ways in tissue engineering: (1) MSCs are first placed on the scaffold then the complex of MSCs and scaffold is cultured; (2) MSCs are first cultured and then placed on the scaffold (Table 2) [104, 105]. A number of scaffolds and nanofibers have been applied in culturing MSCs for their usage in regenerative medicine.

\section{Application of Tissue Engineered-MSCs in Regenerative Medicine}

Application of stem cells in regenerative medicine requires two key elements: (1) the use of stem cells which have high ability in repairing the damaged tissue with the least side effects and (2) designing of biocompatible scaffolds whose clinical use has the least side effects and has no immunologic response. The high ability of proliferation and differentiation to several cell lineages and especially the significant role in immune regulation effects present MSCs as an important source for cell and gene therapy applications in congenital disorders and degenerative diseases [106-108]. Clinical studies reveal that MSCs have high ability in improving allogeneic transplant conditions and reducing side effects caused by chronic reaction of transplant against the host, known as chronic graft versus host disease (cGVHD). In fact, these cells reveal their anti-inflammatory effects by activating inhibitory $\mathrm{T}$ lymphocytes and discharging some immunoregulatory agents. On the other hand, these cells also have the ability to recognise damaged region with their paracrine activity, implant themselves in the region and speed up the repair process $[109,110]$. There are acceptable reports on application of MSCs in remediation of some human diseases such as osteogenesis imperfecta, spinal cord lesions, Parkinson's disease, and brain stroke [111-114]. Recently, scientists developed PLA/PCEC hybrid fibrous scaffolds to effectively differentiate placenta-derived MSCs into boneassociated cells and verified the capacity of this scaffold in bone tissue engineering [115].

In another study Lü and colleagues in 2013 demonstrated that $3 \mathrm{D} \mathrm{PHBV} / \mathrm{HA}$ scaffolds can induce the differentiation of rat bone marrow derived-MSCs into osteoblast cells. These fibrous scaffolds also displayed remarkable effects on the repair of significant defects of bones, presenting their promising usages in bone tissue engineering [116]. In another attempt, scientist applied hydrogel scaffolds to successfully proceed with the differentiation of hMSCs to chondrocytes [117].

This review will discuss further application of tissue engineering technique in generating MSC-based tissue for treatment of vascular diseases, bone lesions, cartilage diseases, and bladder and lung cancers.

\section{Vascular Disease}

In vascular tissue engineering, cells derived from BM are utilized. This technique requires plating a mixture of cells recognized as bone marrow stromal cells (BMSCs) in culture dishes to achieve attached cell population. Prior to scaffold seeding, the BMSCs are differentiated to vascular cells. Nevertheless, long phases of cell expansion, high price of different growth factors, reiterated enzymatic digestion, and potential restrictions in cell behaviour which result in supraphysiologic inflexibility of cell culture dishes are the obstacles that should be overcome [118].

Alternatively, bone marrow mononuclear cells (BMNCs), a heterogeneous population containing differently mature Bcells, T-cells, and monocytes, as well as hematopoietic stem cells (HScs), MSCs, endothelial progenitor cells (EPCs), and very small embryonic-like cells (VSELs), could be isolated in order to avoid the long adhesion stage in cell culture dishes. Unlike BMSCs, BMNCs can be directly seeded into the anticipated scaffolds, which could be beneficial in preservation of cell phenotype, viability, and even simplifying the in vitro processes. Previous studies showed that culturing 
TABLE 1: Sources for isolation of mesenchymal stem cells.

\begin{tabular}{|c|c|c|c|c|}
\hline Tissue & Isolation protocol & $\begin{array}{l}\text { Properties of isolated } \\
\text { cells }\end{array}$ & $\begin{array}{l}\text { Marker of interest in } \\
\text { isolated cells }\end{array}$ & Resource \\
\hline $\begin{array}{l}\text { Warton's jelly of } \\
\text { UCB }\end{array}$ & $\begin{array}{l}\text { Sections of Warton's jelly } \\
\text { in medium, taking out } \\
\text { the sections from the } \\
\text { medium after } 5 \text { days, and } \\
\text { culture of isolated cells } \\
\text { for } 5 \text { more days. }\end{array}$ & $\begin{array}{l}\text { Isolated MSCs probably } \\
\text { lack pluripotency } \\
\text { according to lack of } \\
\text { NANOG gene } \\
\text { expression after 9th } \\
\text { culture. }\end{array}$ & $\begin{array}{l}\text { Histochemical study in } \\
\text { terms of alkaline } \\
\text { phosphatase activity, } \\
\text { RT-PCR to study the } \\
\text { existence of NANOG } \\
\text { mRNA, examining } \\
\text { growth graph of isolated } \\
\text { cells. }\end{array}$ & {$[7]$} \\
\hline Knee synovium & $\begin{array}{l}\text { Collagenase treatment of } \\
\text { human knee synovium } \\
\text { tissue, cell culture, and } \\
\text { attachment of MSCs to } \\
\text { flask. }\end{array}$ & $\begin{array}{l}\text { Isolation from synovium } \\
\text { tissue sectioned during } \\
\text { knee surgery, high } \\
\text { proliferation power } \\
\text { compared to similar } \\
\text { types, high } \\
\text { differentiation potential } \\
\text { into adipose and } \\
\text { cartilage tissue. }\end{array}$ & $\begin{array}{l}\text { Immunohistochemistry } \\
\text { and flow cytometry for } \\
\text { CD105 and CD73, gene } \\
\text { study with RT-PCR, and } \\
\text { specific dying for cells } \\
\text { induced towards } \\
\text { osteocyte and } \\
\text { adipocytes. }\end{array}$ & {$[8]$} \\
\hline Amnion & $\begin{array}{l}\text { EDTA and trypsin } \\
\text { treatment, cell culture in } \\
\text { DMEM medium with } \\
10 \% \text { FBS. }\end{array}$ & $\begin{array}{l}\text { MSCs remained } \\
\text { undifferentiated after } \\
18-20 \text { steps of passages, } \\
\text { these cells beside high } \\
\text { differentiation potential } \\
\text { into mesodermal cell } \\
\text { line, can differentiate } \\
\text { into nerve-like cells. }\end{array}$ & $\begin{array}{l}\text { Flow cytometry for } \\
\text { CD34, CD } 45, \text { CD73, } \\
\text { CD90, and CD105 and } \\
\text { then differentiation into } \\
\text { osteoblasts, adipocytes, } \\
\text { and nerve cell line. }\end{array}$ & {$[9]$} \\
\hline Eye conjunctiva & $\begin{array}{l}\text { After biopsy, stromal } \\
\text { section of eye } \\
\text { conjunctiva tissue was } \\
\text { cultured in flask. }\end{array}$ & $\begin{array}{l}\text { These cells, other than } \\
\text { osteoblasts, } \\
\text { chondroblasts and } \\
\text { adipogenic cells, have } \\
\text { the potential to } \\
\text { differentiate into nerve } \\
\text { cells. }\end{array}$ & $\begin{array}{l}\text { Expression of markers } \\
\text { like CD29, CD44, } \\
\text { CD166, CD13, and SH2 } \\
\text { and SH3 and genes such } \\
\text { as Oct-4, Rex-1, and } \\
\text { NANOG. }\end{array}$ & {$[10]$} \\
\hline Endometrium & $\begin{array}{l}\text { Collagenase III and } \\
\text { ribonuclease I treatment } \\
\text { of endometrium to } \\
\text { produce single cell } \\
\text { suspension, removal of } \\
\text { leukocytes by } \\
\text { anti-PTPRC } \\
\text { (anti-CD45), and culture } \\
\text { of MSCs and epithelial } \\
\text { cells in DMEM/F-12 } \\
\text { with } 10 \% \text { FBS, isolating } \\
\text { epithelial cells using } \\
\text { anti-EpCAM. }\end{array}$ & $\begin{array}{l}\text { MSCs produced have } \\
\text { high potential of } \\
\text { self-renewal and } \\
\text { differentiation into } \\
\text { osteoblasts, } \\
\text { chondrocytes, } \\
\text { adipocytes and smooth } \\
\text { muscles. }\end{array}$ & $\begin{array}{l}\text { Flow cytometry and } \\
\text { immunohistochemistry } \\
\text { for expression of ITGB1 } \\
\text { (CD29), CD44, NT5E } \\
\text { (CD73), THY1 (CD90), } \\
\text { ENG (CD105), PDGFRB } \\
\text { (CD140B), and MCAM } \\
\text { (CD146) and lack of } \\
\text { expression of PECAM1 } \\
\text { (CD31), CD34, PTPRC } \\
\text { (CD45), and EpCAM. }\end{array}$ & {$[11]$} \\
\hline Adipose tissue & $\begin{array}{l}\text { Collagenase III } \\
\text { treatment of adipose } \\
\text { tissue to produce single } \\
\text { cell suspension, culture } \\
\text { in ultraculture medium } \\
\text { with } 2 \% \text { UltroserG. }\end{array}$ & $\begin{array}{l}\text { MSCs have ability of fast } \\
\text { proliferation and } \\
\text { differentiation potential } \\
\text { into osteoblasts and } \\
\text { adipocytes. }\end{array}$ & $\begin{array}{l}\text { Flow cytometry for } \\
\text { expression of CD73, } \\
\text { CD90, CD105, CD44, } \\
\text { and CD166 and lack of } \\
\text { expression of CD45, } \\
\text { CD34, and CD14. }\end{array}$ & {$[12]$} \\
\hline
\end{tabular}

vascular smooth muscle cells (VSMCs) on PGS scaffolds demonstrated the expression of elastin and amenability with higher similarity to native vessels than the cells cultured on firmer but more chemically analogous PLGA scaffolds
[119]. Another study revealed that the PGS scaffolds could be precoated with natural matrix which improves the functional proteins expression and extracellular matrix (ECM) in endothelial progenitor cells (EPC) [120]. The obtained data 
TABLE 2: Sources of MSCs and scaffolds used in regenerative medicine.

\begin{tabular}{|c|c|c|c|}
\hline MSC source & Illness & Scaffold and nanofiber & Resource \\
\hline Human BM & Liver lesions & PCL/collagen/PES nanofiber scaffold & {$[52]$} \\
\hline Mouse BM & Vascular lesions & 1-PLGA, PGS, P-PGS, Pl-P-PGS & {$[53]$} \\
\hline Murine BM & Skin lesions & Integra $(\mathrm{R})$, an artificial dermal matrix & {$[54]$} \\
\hline $\begin{array}{l}\text { Human adipose } \\
\text { tissue }\end{array}$ & Bone lesions & Chitosan-based scaffolds & {$[55]$} \\
\hline $\mathrm{BM}$ & Vascular lesion & Polyelectrolyte multilayer film & {$[56]$} \\
\hline $\mathrm{BM}$ & Bone lesions & $\begin{array}{l}\text { Thin film of PEGylated multiwalled } \\
\text { carbon nanotubes spray dried onto } \\
\text { preheated coverslip }\end{array}$ & {$[57]$} \\
\hline $\begin{array}{l}\text { Induced } \\
\text { pluripotent cells }\end{array}$ & $\begin{array}{l}\text { Bone and cartilage } \\
\text { lesions }\end{array}$ & Calcified Structures in Scaffold & {$[58]$} \\
\hline $\mathrm{BM}$ & Skin lesions & $\begin{array}{l}\text { Pullulan-collagen composite hydrogel } \\
\text { matrices }\end{array}$ & {$[59]$} \\
\hline Sheep BM & $\begin{array}{l}\text { Cardiac valves } \\
\text { lesions }\end{array}$ & PGA : PLLA scaffolds & {$[60]$} \\
\hline Human BM & Vascular lesions & PLLA/PCL & {$[61]$} \\
\hline Human BM & Cartilage lesions & $\begin{array}{l}\text { Fresh fibrin (FG) and platelet-rich } \\
\text { fibrin (PR-FG) glues produced by the } \\
\text { CryoSeal (R) FS System }\end{array}$ & {$[62]$} \\
\hline Human BM & Bone lesions \& & Coral scaffold & {$[63]$} \\
\hline Human BM & $\begin{array}{l}\text { Bone and cartilage } \\
\text { lesions }\end{array}$ & LIFT three-dimensional scaffold & {$[64]$} \\
\hline Human BM & Vascular lesions & Heparin-releasing PLLA & {$[65]$} \\
\hline Adipose tissue & $\begin{array}{l}\text { Muscular and } \\
\text { skeletal lesions }\end{array}$ & $\begin{array}{l}\text { Biomaterial scaffolds consisting of } \\
\text { native tissue matrices derived from } \\
\text { cartilage }\end{array}$ & {$[66]$} \\
\hline $\mathrm{BM}$ & Bone lesions & 3D silk scaffolds & {$[67]$} \\
\hline Adipose tissue & Bone lesions & Trabecular titanium scaffolds & {$[68]$} \\
\hline $\mathrm{BM}$ & Bone lesions & Scaffold-free cell sheet & {$[69]$} \\
\hline $\mathrm{BM}$ & Bladder lesions & $\begin{array}{l}\text { Nanofibrous poly-L-lactic acid } \\
\text { scaffolds }\end{array}$ & {$[70]$} \\
\hline Sheep lung & Lung lesions & $\begin{array}{l}\text { Fibrinogen- } \backslash \text { fibronectin-vitronectin } \\
\text { hydrogel (FFVH) scaffolds }\end{array}$ & {$[71]$} \\
\hline $\begin{array}{l}\text { Rat, pig, and rabbit } \\
\text { adipose tissue }\end{array}$ & Bone lesions & Hydroxyapatite scaffolds & {$[72]$} \\
\hline $\mathrm{BM}$ & Bladder lesions & $\begin{array}{l}\text { 3D nanofibrous scaffold, highly porous } \\
\text { PLLA scaffold }\end{array}$ & {$[73]$} \\
\hline $\mathrm{BM}$ & Bone lesions & $\begin{array}{l}\text { cell-scaffold construct composed of } \\
\text { gelatin-based hydrogel and ceramic } \\
(\mathrm{CaCO} / \text { beta-TCP) particles }\end{array}$ & {$[74]$} \\
\hline $\mathrm{BM}$ & Bone lesions & Pura matrix (PM) & {$[75]$} \\
\hline $\mathrm{BM}$ & Cartilage lesions & 3D chitosan scaffold & {$[76]$} \\
\hline $\mathrm{BM}$ & Bone lesions & $\begin{array}{l}\text { Biodegradable chitosan/polyester } \\
\text { scaffold }\end{array}$ & {$[77]$} \\
\hline $\mathrm{BM}$ & & Poly (L-lactic acid) microfiber & {$[78]$} \\
\hline Rat BM & Bone lesions & $\begin{array}{l}\text { Nonporous, smart, and stimulus } \\
\text { responsive chitosan-based scaffolds }\end{array}$ & {$[79]$} \\
\hline $\mathrm{BM}$ & Vascular lesions & 3D calcium phosphate $(\mathrm{CP})$ scaffolds & {$[80]$} \\
\hline $\mathrm{BM}$ & Bone lesions & Porous hydroxyapatite ceramics & {$[81]$} \\
\hline $\mathrm{BM}$ & Bone lesions & Hydroxyapatite scaffolds & {$[82]$} \\
\hline $\mathrm{BM}$ & Teeth lesions & Collagen scaffold carrier & {$[83]$} \\
\hline $\mathrm{BM}$ & Bone lesions & Porous collagen I/III scaffold & {$[84]$} \\
\hline
\end{tabular}


TABLe 2: Continued.

\begin{tabular}{lllc}
\hline MSC source & Illness & Scaffold and nanofiber & Resource \\
\hline BM & Nerve lesions & PLGA polymer scaffold & {$[85]$} \\
BM & Bone lesions & Ceramic scaffolds & {$[86]$} \\
BM & Bone lesions & PLA & {$[87]$} \\
Amniotic Fluid & Sinus & MgHA/collagen based scaffold & {$[88]$} \\
BM & augmentation & Collagen nanofibrous scaffold & {$[89]$} \\
\hline
\end{tabular}

BM: bone marrow.

recommended that creating an environment with features similar to blood vessels in vitro could enhance the establishment of vascular tissues derived from progenitor cells. A recent study demonstrated the use of BMNCs with platelets plasma proteins and PGS for vascular tissue development. In the study, they exhibited that biochemical mechanisms and tissue signals from platelets and plasma can together direct BMNCs to change into cells similar to smooth muscle which have the expression of phenotypic markers and individual ECM production [52].

\section{Bone Lesions}

Another application of MSCs in tissue engineering is the use of these cells to differentiate into bone cells in order to remedy large bone lesions due to trauma or degenerative pathologic damages. As autologous bone transplant has some limitations, application of tissue engineering to regenerate bone lesions using three-dimensional (3D) scaffold MSCs has been proposed [121]. In fact, designing a scaffold that is able to act like a proper support for attachment and proliferation of cells and inducing differentiation into bone cell lines and provide a porous space for appropriate connection between cells in order to reach bone regeneration is a heatedly debated topic. In a preclinical application, the complex of scaffold and MSCs was placed under mouse's skull to study the ability of MSCs to form bone cells. Results showed significant acceleration in regeneration of bone tissue in maxillary sinus using MSCs. In fact histomorphological studies reveal the formation of osteoblasts with the potential of forming an osteoid matrix with the assistance of biphasic HA/TCP scaffolds [122].

Chemical vapor deposition- (CVD-) developed graphene- (G-) sheets display brilliant features in stimulating osteogenic differentiation of MSCs [123]. Lee et al. [124] demonstrated that CVD-developed G-sheets can significantly promote osteogenic differentiation of hMSCs alongside with chemical growth factors. They also found that the presence of chemical inducers highly increased the amount of osteogenic differentiation on G-sheets. Unfortunately, they [125] further discovered that G-sheets were not capable of absorbing enough ascorbic acid which required chemical inducers in the generation of mature osteoblasts [126].

Other nanomaterials containing carbon nanotubes (CNTs) [127] and gold nanoparticles [123] could also promote osteogenic differentiation of MSCs by means of stress mechanism. This method utilizes physical stressor to promote the differentiation of stem cells into various cell lineages $[128,129]$. As an example, Dalby et al. [130] showed that proliferation of MSCs on poly-(methylmethacrylate) (PMMA) nanopatterns and in a standard culture medium resulted in the formation of osteoblastic morphologies without utilization of chemical inducers. In addition to such synthetic nanomaterials, it was also demonstrated that usage of some bionanomaterials such as tobacco mosaic virus can also improve the differentiation of stem cells [131].

A recent experience reported the formation of two novel nanostructures, graphene oxide nanoribbon (GONR) and reduced GONR, as two-dimensional (2D) templates to investigate the application of graphene nanostructures in osteogenic differentiation of MSCs with or without the utilization of various chemical inducers. They studied the effects of physical stresses induced by surface topography of the nanogrids on the differentiation of MSCs. The results showed that the utilization of chemical inducers stimulates the reduced graphene oxide nanoribbon (rGONR) grids to display osteogenic differentiation in a short period. These achievements can promote further research on selective differentiation of stem cells on different graphene constructs as biocompatible and implantable scaffolds even with $3 \mathrm{D}$ configurations [18]. However, the use of tissue engineering in regeneration of bone lesions has some limitations due to low number of stem cells isolated from BM aspiration [49]. In the end, finding novel sources for MSCs derivation like amniotic fluid and Warton's jelly along with more research about application of different scaffolds for proliferation and differentiation of MSCs and clinical monitoring of implanted MSCs are required $[132,133]$.

\section{Cartilage Disease}

The application of various adult-derived stem cells (ASCs) in tissue engineering approaches is considered as a novel method to console the trouble of cell, organ, and tissue scarcity. Cartilage flaws that caused by joint injury, developmental disorders, and aging resulted result in the pain of joints and loss of movement. Tissue engineering methods suggest particular cell-based treatment to overhaul articular cartilage flaws and provide a capable method for reestablishment of joint function [134, 135]. In cartilage tissue engineering methods, chondrocytes and MSCs are normally 
utilized for redevelopment of cartilage, but the type of cells will determine the tissue engineering approaches of cartilage in vitro. Although expansion of MSCs for regeneration of cartilage is at an initial step, the noticeable MSCs plasticity could supply tissue engineering with ample possibility of utilizing MSCs for manifold cellular differentiation for obtaining strictly multiphasic tissues [136, 137].

To stimulate chondrogenic differentiation, MSCs are proliferated in a $3 \mathrm{D}$ situation to improve the need of interaction between cells [138]. Earlier studies have shown that MSCs displayed chondrogenic characteristics when are propagated in a culture $[139,140]$, a technique which was generally utilized in MSC chondrogenesis analysis [141, 142]. Nevertheless, the technique of cell pellet propagation has manifold innate weaknesses. Small in magnitude and regularly poor mechanical characteristics have made the technique impracticable to repair cartilage flaws. Predesigned biomaterial scaffolds have much more attractive potential in providing the role as a support structure for MSCs, such as preparing a $3 \mathrm{D}$ situation with comprehensive mechanical features. Some studies developed several natural and synthetic substances [143, 144], produced gel-, sponge-, or fiber-centered constructions constructs to proliferate MSCs of various species [145-147]. The electrospinning procedure is an easy, economical method to generate ultrafine fiber-derived scaffolds developed from a range of different biodegradable polymers $[36,148]$. Nanofiber scaffolds generated through electrospinning method have structures similar to extracellular matrix and can display favourable features for tissue engineering purposes. It has been demonstrated that 3D NFSs are distinguished through high sponginess and similar morphology to natural collagen fibrils, a high ratio of surface area to volume, and wide-ranging pore diameter [149].

These physical structures elevate promising biological responses in cultured cells containing improved proliferation and cell attachment in addition to preservation of the chondrocytic phenotype $[150,151]$. In a study, the chondrogenic functions of seeded BM-MSC maintained on polycaprolactone were compared to the cells cultured using cell pellet technique, in a defined medium supplemented with TGF-b1 [152]. The cultured MSCs showed a chondrocytic phenotype differentiation and cartilage-associated ECM proteins synthesis. These findings reported that PCL NFS is a suitable support structure to transplant the MSCs, which suggests practical scaffolds for cell-based cartilage repair using tissue engineering methods [52].

\section{Bladder Cancer}

Bladder cancer is the ninth most frequent cancer in the world and the incidence is four times higher in males [153] where smoking has been known as a main reason of bladder cancer in western countries [154]. Nowadays, stem cell therapy has become one of the most appropriate therapeutic approaches for bladder cancer. In fact, many studies have shown that bladder smooth muscle cells can be produced from transplanted stem cells $[155,156]$. These studies also showed that smooth muscle cells generated from transplanted stem cells can be really valuable in bladder tissue engineering [73].

MSC is known as an appropriate stem cell source to approach this goal. MSC is able to self-renew and also differentiate into different cell types under certain conducive environments [157, 158]. In fact, using MSC for their therapeutic potentials has been very useful to control and treat different types of cancers including bladder cancer. For instance, stimulation of tissue regeneration and prevention of tissue injury after transplantation of stem cell are also very important [159] and paracrine mechanism of MSCs can play a very important role in this area [160].

Indeed, based on recent literatures, the most important issues that researchers are focusing on are the improvement of the isolation procedure and expansion of these cells. Among various methods small intestinal submucosa (SIS) could successfully be applied for bladder tissue engineering [161].

Tissue engineering scaffolds are one of the appropriate regeneration environments that have been used by researchers to isolate and expand MSCs [162]. Using synthetic scaffolds like poly-lactic-glycolic, for instance, instead of SIS, to generate MSCs [163] has proved to be more practical. Tian et al. exhibited bladder engineering potential when such synthetic scaffold was applied [73]. Similarly, it is shown that using poly-lactic-glycolic acid to expand MSC's lead's to maintenance of bladder capacity and compliance [164]. Current studies introduced novel generation of synthetic polymer scaffolds. These nanofibrous scaffolds have improved biomechanical/physical features and have been used in tissue engineering of various organs. This new product can provide a natural environment which improves cell metabolism by improving the exchange of nutrition and gas [165]. Various attempts have been done to establish this new technology but it still needs more examination.

\section{Lung Cancer}

Lung cancer is the most frequent cancer worldwide with higher incidence in males compared to females [150]. Various methods are available for cancer treatment including the application of engineered tissue; such techniques involve growing lung tissue using artificial scaffold and stem cells ex vivo which has been frequently used in regeneration of lung tissue. Particularly, MSCs isolated from different sources are seeded on various biosynthetic scaffolds to generate tracheal cartilage for repairing congenital tracheal defects $[166,167]$.

Several researchers are focusing on this issue. In one study, fetal rat lung cells were cultured in a biosynthetic gelatin matrix and then injected into normal rat lung which have resulted in induction of lung structure [168]. Another study showed the creation of alveolar-like constructs after culturing fetal rat lung suspensions in a 3D glycosaminoglycan scaffold. Concurrently, seeding the mouse cells in synthetic polymer scaffolds showed the same result [169]. Researchers also showed the ability of 3D scaffold culture systems to assess lung improvement and repair [170]. In fact, 
other studies also showed that stem cells isolated from various sources can form airway or alveolar-like structures when cultivated in scaffolding material and after culturing in such an environment, can be used for functional lung regeneration $[171,172]$. Scaffolds are used to engineer lung airways by several researchers [173, 174]. Gray et al. showed the importance of MSC-engineered scaffolds for engineered perinatal airway repair. They also demonstrated improvement in remodelling and epithelialization in vivo by using engineered human amniotic fluid MSC [175]. Previous studies on engineered airway also showed the same results by using different cells and scaffolds [176, 177]. Revision is still necessary although researchers have found quite a number of appropriate details about synthetic scaffold.

\section{Conclusion}

In this review, the applications of nanoscaffolds and MSCs in regenerative medicine were discussed. Selection of a proper source for isolation of MSCs like amniotic fluids and umbilical cord and designing biocompatible and biodegradable scaffolds proper for proliferation and differentiation into multiple lineages have great significance in regenerative medicine. Further researches in this field can provide a way for advancement of application of tissue engineered-MSCs in regenerative medicine.

\section{Conflict of Interests}

The authors declare that they have no conflict of interests.

\section{References}

[1] R. Murugan and S. Ramakrishna, "Design strategies of tissue engineering scaffolds with controlled fiber orientation," Tissue Engineering, vol. 13, no. 8, pp. 1845-1866, 2007.

[2] L. Zhang and T. J. Webster, "Nanotechnology and nanomaterials: promises for improved tissue regeneration," Nano Today, vol. 4, no. 1, pp. 66-80, 2009.

[3] C. Mason and P. Dunnill, "A brief definition of regenerative medicine," Regenerative Medicine, vol. 3, no. 1, pp. 1-6, 2008.

[4] A. M. Riazi, "Stem cell sources for regenerative medicine," in Stem Cells in Regenerative Medicine, pp. 55-90, Springer, New York, NY, USA, 2009.

[5] C. L. Stoick-Cooper, R. T. Moon, and G. Weidinger, "Advances in signaling in vertebrate regeneration as a prelude to regenerative medicine," Genes and Development, vol. 21, no. 11, pp. 12921315, 2007.

[6] K. Muneoka, C. H. Allan, X. Yang, J. Lee, and M. Han, "Mammalian regeneration and regenerative medicine," Birth Defects Research Part C-Embryo Today: Reviews, vol. 84, no. 4, pp. 265-280, 2008.

[7] M. Maleki, K. Parivar, M. Nabiouni, P. Yaghmaei, and M. Naji, "Isolation of mouse umbilical cord mesenchymal stem cells and its differentiation to lens fiber cells," Journal of Ardabil University of Medical Sciences, vol. 9, no. 2, pp. 164-170, 2009.

[8] M. Kadivar, F. Piryaei, and M. Ramezani, "Comparison of the differentiation potential of human mesenchymal stem cells and several animal species," Koomesh, vol. 11, no. 4, pp. 270-279, 2010.
[9] S. Manochant, C. Tantrawatpa, P. Kheolama, Y. U-pratya, A. Supokawe, and S. Issaragrisi, "Isolation, characterization and neural differentiation potential of amnion derived mesenchymal stem cells," Journal of the Medical Association of Thailand, vol. 93, no. 7, pp. S183-S191, 2010.

[10] S. Nadri, M. Soleimani, J. Kiani, A. Atashi, and R. Izadpanah, "Multipotent mesenchymal stem cells from adult human eye conjunctiva stromal cells," Differentiation, vol. 76, no. 3, pp. 223231, 2008.

[11] C. E. Gargett, K. E. Schwab, R. M. Zillwood, H. P. T. Nguyen, and $\mathrm{D}$. Wu, "Isolation and culture of epithelial progenitors and mesenchymal stem cells from human endometrium," Biology of Reproduction, vol. 80, no. 6, pp. 1136-1145, 2009.

[12] N. Pourhabibi Zarandi, I. Ahrari, A. Attar, M. Khosravi, and A. Monabatti, "Serum-free isolation of adipose tissue derived multipotent mesenchymal stromal cells," Cell Journal, vol. 12, supplement 1, p. 105, 2011.

[13] C. Zhao, A. Tan, G. Pastorin, and H. K. Ho, "Nanomaterial scaffolds for stem cell proliferation and differentiation in tissue engineering," Biotechnology Advances, vol. 31, no. 5, pp. 654668, 2013.

[14] M. F. Pittenger, A. M. Mackay, S. C. Beck et al., "Multilineage potential of adult human mesenchymal stem cells," Science, vol. 284, no. 5411, pp. 143-147, 1999.

[15] L. da Silva Meirelles, P. C. Chagastelles, and N. B. Nardi, "Mesenchymal stem cells reside in virtually all post-natal organs and tissues," Journal of Cell Science, vol. 119, no. 11, pp. 22042213, 2006.

[16] D. Liang, B. S. Hsiao, and B. Chu, "Functional electrospun nanofibrous scaffolds for biomedical applications," Advanced Drug Delivery Reviews, vol. 59, no. 14, pp. 1392-1412, 2007.

[17] E. Seyedjafari, M. Soleimani, N. Ghaemi, and M. N. Sarbolouki, "Enhanced osteogenic differentiation of cord blood-derived unrestricted somatic stem cells on electrospun nanofibers," Journal of Materials Science: Materials in Medicine, vol. 22, no. 1, pp. 165-174, 2011.

[18] O. Akhavan, E. Ghaderi, and M. Shahsavar, "Graphene nanogrids for selective and fast osteogenic differentiation of human mesenchymal stem cells," Carbon, vol. 59, pp. 200-211, 2013.

[19] T. Yin and L. Li, "The stem cell niches in bone," Journal of Clinical Investigation, vol. 116, no. 5, pp. 1195-1201, 2006.

[20] E. J. Moerman, K. Teng, D. A. Lipschitz, and B. LeckaCzernik, "Aging activates adipogenic and suppresses osteogenic programs in mesenchymal marrow stroma/stem cells: the role of PPAR- $\gamma 2$ transcription factor and TGF- $\beta /$ BMP signaling pathways," Aging Cell, vol. 3, no. 6, pp. 379-389, 2004.

[21] A. A. Worster, B. D. Brower-Toland, L. A. Fortier, S. J. Bent, J. Williams, and A. J. Nixon, "Chondrocytic differentiation of mesenchymal stem cells sequentially exposed to transforming growth factor- $\beta 1$ in monolayer and insulin-like growth factor-I in a three-dimensional matrix," Journal of Orthopaedic Research, vol. 19, no. 4, pp. 738-749, 2001.

[22] Y. Mohammadi, H. Mirzadeh, F. Moztarzadeh, M. Soleimani, and E. Jabbari, "Osteogenic differentiation of mesenchymal stem cells on novel three-dimensional poly(Llactic acid)/chitosan/gelatin/ $\beta$-tricalcium phosphate hybrid scaffolds," Iranian Polymer Journal, vol. 16, no. 1, pp. 57-69, 2007.

[23] M. V. Risbud, I. M. Shapiro, A. Guttapalli et al., "Osteogenic potential of adult human stem cells of the lumbar vertebral body and the iliac crest," Spine, vol. 31, no. 1, pp. 83-89, 2006. 
[24] W.-M. Yue, W. Liu, Y.-W. Bi et al., "Mesenchymal stem cells differentiate into an endothelial phenotype, reduce neointimal formation, and enhance endothelial function in a rat vein grafting model," Stem Cells and Development, vol. 17, no. 4, pp. 785-793, 2008

[25] B. M. Strem, M. Zhu, Z. Alfonso et al., "Expression of cardiomyocytic markers on adipose tissue-derived cells in a murine model of acute myocardial injury," Cytotherapy, vol. 7, no. 3, pp. 282-291, 2005.

[26] J. Sanchez-Ramos, S. Song, F. Cardozo-Pelaez et al., "Adult bone marrow stromal cells differentiate into neural cells in vitro," Experimental Neurology, vol. 164, no. 2, pp. 247-256, 2000.

[27] H. Aurich, M. Sgodda, P. Kaltwaßer et al., "Hepatocyte differentiation of mesenchymal stem cells from human adipose tissue in vitro promotes hepatic integration in vivo," Gut, vol. 58 , no. 4 , pp. 570-581, 2009.

[28] S. H. Oh, T. M. Muzzonigro, S. H. Bae, J. M. LaPlante, H. M. Hatch, and B. E. Petersen, "Adult bone marrow-derived cells trans differentiating into insulin-producing cells for the treatment of type I diabetes," Laboratory Investigation, vol. 84, no. 5, pp. 607-617, 2004.

[29] A. J. Friedenstein, U. F. Gorskaja, and N. N. Kulagina, "Fibroblast precursors in normal and irradiated mouse hematopoietic organs," Experimental Hematology, vol. 4, no. 5, pp. 267-274, 1976.

[30] S. Sun, Z. Guo, X. Xiao et al., "Isolation of mouse marrow mesenchymal progenitors by a novel and reliable method," Stem Cells, vol. 21, no. 5, pp. 527-535, 2003.

[31] M. Soleimani and S. Nadri, "A protocol for isolation and culture of mesenchymal stem cells from mouse bone marrow," Nature Protocols, vol. 4, no. 1, pp. 102-106, 2009.

[32] E. J. Schwarz, G. M. Alexander, D. J. Prockop, and S. A. Azizi, "Multipotential marrow stromal cells transduced to produce L-DOPA: engraftment in a rat model of Parkinson disease," Human Gene Therapy, vol. 10, no. 15, pp. 2539-2549, 1999.

[33] A. Alhadlaq and J. J. Mao, "Mesenchymal stem cells: isolation and therapeutics," Stem Cells and Development, vol. 13, no. 4, pp. 436-448, 2004.

[34] C. T. Brighton and R. M. Hunt, "Early histologic and ultrastructural changes in microvessels of periosteal callus," Journal of Orthopaedic Trauma, vol. 11, no. 4, pp. 244-253, 1997.

[35] L. D. S. Meirelles and N. B. Nardi, "Murine marrow-derived mesenchymal stem cell: isolation, in vitro expansion, and characterization," British Journal of Haematology, vol. 123, no. 4, pp. 702-711, 2003.

[36] M. B. Eslaminejad, A. Nikmahzar, L. Taghiyar, S. Nadri, and M. Massumi, "Murine mesenchymal stem cells isolated by low density primary culture system," Development Growth and Differentiation, vol. 48, no. 6, pp. 361-370, 2006.

[37] M. S. Tsai, J. L. Lee, Y. J. Chang, and S. M. Hwang, "Isolation of human multipotent mesenchymal stem cells from secondtrimester amniotic fluid using a novel two-stage culture protocol," Human Reproduction, vol. 19, no. 6, pp. 1450-1456, 2004.

[38] P. de Coppi, G. Bartsch Jr., M. M. Siddiqui et al., "Isolation of amniotic stem cell lines with potential for therapy," Nature Biotechnology, vol. 25, no. 1, pp. 100-106, 2007.

[39] S. A. Wexler, C. Donaldson, P. Denning-Kendall, C. Rice, B. Bradley, and J. M. Hows, "Adult bone marrow is a rich source of human mesenchymal "stem" cells but umbilical cord and mobilized adult blood are not," British Journal of Haematology, vol. 121, no. 2, pp. 368-374, 2003.
[40] M. Yu, Z. Xiao, L. Shen, and L. Li, "Mid-trimester fetal blood-derived adherent cells share characteristics similar to mesenchymal stem cells but full-term umbilical cord blood does not," British Journal of Haematology, vol. 124, no. 5, pp. 666-675, 2004.

[41] O. K. Lee, T. K. Kuo, W. M. Chen, K. D. Lee, S. L. Hsieh, and T. H. Chen, "Isolation of multipotent mesenchymal stem cells from umbilical cord blood," Blood, vol. 103, no. 5, pp. 1669-1675, 2004.

[42] D. T. Covas, J. L. C. Siufi, A. R. L. Silva, and M. D. Orellana, "Isolation and culture of umbilical vein mesenchymal stem cells," Brazilian Journal of Medical and Biological Research, vol. 36, no. 9, pp. 1179-1183, 2003.

[43] A. Peister, J. A. Mellad, B. L. Larson, B. M. Hall, L. F. Gibson, and D. J. Prockop, "Adult stem cells from bone marrow (MSCs) isolated from different strains of inbred mice vary in surface epitopes, rates of proliferation, and differentiation potential," Blood, vol. 103, no. 5, pp. 1662-1668, 2004.

[44] T. Kinashi, Y. S. Pierre, and T. A. Springer, "Expression of glycophosphatidylinositol-anchored and -non-anchored isoforms of vascular cell adhesion molecule 1 in murine stromal and endothelial cells," Journal of Leukocyte Biology, vol. 57, no. 1, pp. 168-173, 1995.

[45] S. Schrepfer, T. Deuse, C. Lange et al., "Simplified protocol to isolate, purify, and culture expand mesenchymal stem cells," Stem Cells and Development, vol. 16, no. 1, pp. 105-108, 2007.

[46] R. Huss, "Perspectives on the morphology and biology of CD34negative stem cells," Journal of Hematotherapy \& Stem Cell Research, vol. 9, no. 6, pp. 783-793, 2000.

[47] S. K. Brusnahan, T. R. McGuire, J. D. Jackson et al., "Human blood and marrow side population stem cell and Stro-1 positive bone marrow stromal cell numbers decline with age, with an increase in quality of surviving stem cells: correlation with cytokines," Mechanisms of Ageing and Development, vol. 131, no. 11-12, pp. 718-722, 2010.

[48] S. Gronthos and P. J. Simmons, "The growth factor requirements of STRO-1-positive human bone marrow stromal precursors under serum-deprived conditions in vitro," Blood, vol. 85 , no. 4, pp. 929-940, 1995.

[49] Y. Xiao, S. R. Mareddy, and R. W. Crawford, "Clonal characterization of bone marrow derived stem cells and their application for bone regeneration," International Journal of Oral Science, vol. 2, no. 3, pp. 127-135, 2010.

[50] C. Martinez, T. J. Hofmann, R. Marino, M. Dominici, and E. M. Horwitz, "Human bone marrow mesenchymal stromal cells express the neural ganglioside GD2: a novel surface marker for the identification of MSCs," Blood, vol. 109, no. 10, pp. 42454248, 2007.

[51] E. J. Gang, D. Bosnakovski, C. A. Figueiredo, J. W. Visser, and R. C. R. Perlingeiro, "SSEA-4 identifies mesenchymal stem cells from bone marrow," Blood, vol. 109, no. 4, pp. 1743-1751, 2007.

[52] W. Wu, R. Allen, J. Gao, and Y. Wang, "Artificial niche combining elastomeric substrate and platelets guides vascular differentiation of bone marrow mononuclear cells," Tissue Engineering - Part A, vol. 17, no. 15-16, pp. 1979-1992, 2011.

[53] C. Li, Y. Zheng, X. Wang et al., "Bone marrow-derived stem cells contribute skin regeneration in skin and soft tissue expansion," Journal of Cellular Physiology, vol. 226, no. 11, pp. 2834-2840, 2011.

[54] A. R. Costa-Pinto, V. M. Correlo, P. C. Sol et al., "Chitosanpoly(butylene succinate) scaffolds and human bone marrow 
stromal cells induce bone repair in a mouse calvaria model," Journal of Tissue Engineering and Regenerative Medicine, vol. 6, no. 1, pp. 21-28, 2012.

[55] T. Rada, T. C. Santos, A. P. Marques et al., "Osteogenic differentiation of two distinct subpopulations of human adiposederived stem cells: an in vitro and in vivo study," Journal of Tissue Engineering and Regenerative Medicine, vol. 6, no. 1, pp. 1-11, 2012.

[56] V. Moby, P. Labrude, A. Kadi, L. Bordenave, J. F. Stoltz, and P. Menu, "Polyelectrolyte multilayer film and human mesenchymal stem cells: an attractive alternative in vascular engineering applications," Journal of Biomedical Materials Research A, vol. 96, no. 2, pp. 313-319, 2011.

[57] T. R. Nayak, L. Jian, L. C. Phua, H. K. Ho, Y. Ren, and G. Pastorin, "Thin films of functionalized multiwalled carbon nanotubes as suitable scaffold materials for stem cells proliferation and bone formation," ACS Nano, vol. 4, no. 12, pp. 7717-7725, 2010.

[58] G. Bilousova, D. H. Jun, K. B. King et al., "Osteoblasts derived from induced pluripotent stem cells form calcified structures in scaffolds both in vitro and in vivo," Stem Cells, vol. 29, no. 2, pp. 206-216, 2011.

[59] V. W. Wong, K. C. Rustad, M. G. Galvez et al., "Engineered pullulan-collagen composite dermal hydrogels improve early cutaneous wound healing," Tissue Engineering A, vol. 17, no. 5-6, pp. 631-644, 2010.

[60] C. E. Eckert, B. T. Mikulis, D. Gottlieb et al., "Three-dimensional quantitative micromorphology of pre- and post-implanted engineered heart valve tissues," Annals of Biomedical Engineering, vol. 39, no. 1, pp. 205-222, 2011.

[61] M. Centola, A. Rainer, C. Spadaccio, S. de Porcellinis, J. A. Genovese, and M. Trombetta, "Combining electrospinning and fused deposition modeling for the fabrication of a hybrid vascular graft," Biofabrication, vol. 2, no. 1, Article ID 014102, 2010.

[62] T. A. E. Ahmed, A. Giulivi, M. Griffith, and M. Hincke, "Fibrin glues in combination with mesenchymal stem cells to develop a tissue-engineered cartilage substitute," Tissue EngineeringPart A, vol. 17, no. 3-4, pp. 323-335, 2011.

[63] C. T. Tran, C. Gargiulo, H. D. Thao, H. M. Tuan, L. Filgueira, and D. M. Strong, "Culture and differentiation of osteoblasts on coral scaffold from human bone marrow mesenchymal stem cells," Cell and Tissue Banking, vol. 12, no. 4, pp. 247-261, 2011.

[64] M. Gruene, A. Deiwick, L. Koch et al., "Laser printing of stem cells for biofabrication of scaffold-free autologous grafts," Tissue Engineering C: Methods, vol. 17, no. 1, pp. 79-87, 2010.

[65] C. Spadaccio, A. Rainer, M. Centola et al., "Heparin-releasing scaffold for stem cells: a differentiating device for vascular aims," Regenerative Medicine, vol. 5, no. 4, pp. 645-657, 2010.

[66] F. Guilak, B. T. Estes, B. O. Diekman, F. T. Moutos, and J. M. Gimble, "2010 Nicolas Andry Award: multipotent adult stem cells from adipose tissue for musculoskeletal tissue engineering," Clinical Orthopaedics and Related Research, vol. 468, no. 9, pp. 2530-2540, 2010.

[67] S. H. Park, E. S. Gil, H. Shi, H. J. Kim, K. Lee, and D. L. Kaplan, "Relationships between degradability of silk scaffolds and osteogenesis," Biomaterials, vol. 31, no. 24, pp. 6162-6172, 2010.

[68] G. Gastaldi, A. Asti, M. F. Scaffino et al., "Human adiposederived stem cells (hASCs) proliferate and differentiate in osteoblast-like cells on trabecular titanium scaffolds," Journal of Biomedical Materials Research A, vol. 94, no. 3, pp. 790-799, 2010.

[69] M. Akahane, H. Shigematsu, M. Tadokoro et al., "Scaffold-free cell sheet injection results in bone formation," Journal of Tissue Engineering and Regenerative Medicine, vol. 4, no. 5, pp. 404411, 2010.

[70] H. Tian, S. Bharadwaj, Y. Liu, P. X. Ma, A. Atala, and Y. Zhang, "Differentiation of human bone marrow mesenchymal stem cells into bladder cells: potential for urological tissue engineering," Tissue Engineering A, vol. 16, no. 5, pp. 1769-1779, 2010.

[71] E. P. Ingenito, E. Sen, L. W. Tsai, S. Murthy, and A. Hoffman, "Design and testing of biological scaffolds for delivering reparative cells to target sites in the lung," Journal of Tissue Engineering and Regenerative Medicine, vol. 4, no. 4, pp. 259-272, 2010.

[72] E. Arrigoni, S. Lopa, L. De Girolamo, D. Stanco, and A. T. Brini, "Isolation, characterization and osteogenic differentiation of adipose-derived stem cells: From small to large animal models," Cell and Tissue Research, vol. 338, no. 3, pp. 401-411, 2009.

[73] H. Tian, S. Bharadwaj, Y. Liu et al., "Myogenic differentiation of human bone marrow mesenchymal stem cells on a 3D nano fibrous scaffold for bladder tissue engineering," Biomaterials, vol. 31, no. 5, pp. 870-877, 2010.

[74] D. Ben-David, T. Kizhner, E. Livne, and S. Srouji, "A tissuelike construct of human bone marrow MSCs composite scaffold support in vivo ectopic bone formation," Journal of Tissue Engineering and Regenerative Medicine, vol. 4, no. 1, pp. 30-37, 2010.

[75] R. Yoshimi, Y. Yamada, K. Ito et al., "Self-assembling peptide nanofiber scaffolds, platelet-rich plasma, and mesenchymal stem cells for injectable bone regeneration with tissue engineering," Journal of Craniofacial Surgery, vol. 20, no. 5, pp. 1523-1530, 2009.

[76] N. M. Breyner, R. C. R. Hell, L. R. P. Carvalho et al., "Effect of a three-dimensional chitosan porous scaffold on the differentiation of mesenchymal stem cells into chondrocytes," Cells Tissues Organs, vol. 191, no. 2, pp. 119-128, 2010.

[77] A. R. Costa-Pinto, V. M. Correlo, P. C. Sol et al., "Osteogenic differentiation of human bone marrow mesenchymal stem cells seeded on melt based chitosan scaffolds for bone tissue engineering applications," Biomacromolecules, vol. 10, no. 8, pp. 2067-2073, 2009.

[78] D. D’Alessandro, B. Battolla, L. Trombi et al., "Embedding methods for poly(l-lactic acid) microfiber mesh/human mesenchymal stem cell constructs," Micron, vol. 40, no. 5-6, pp. 605-611, 2009.

[79] A. M. Martins, Q. P. Pham, P. B. Malafaya et al., "Natural stimulus responsive scaffolds/cells for bone tissue engineering: influence of lysozyme upon scaffold degradation and osteogenic differentiation of cultured marrow stromal cells induced by CaP coatings," Tissue Engineering-Part A, vol. 15, no. 8, pp. 19531963, 2009.

[80] E. K. Moioli, P. A. Clark, M. Chen et al., "Synergistic actions of hematopoietic and mesenchymal stem/progenitor cells in vascularizing bioengineered tissues," PLoS ONE, vol. 3, no. 12, Article ID e3922, 2008.

[81] H. Yoshikawa, N. Tamai, T. Murase, and A. Myoui, "Interconnected porous hydroxyapatite ceramics for bone tissue engineering," Journal of the Royal Society Interface, vol. 6, supplement 3, pp. S341-S348, 2009.

[82] L. Ciocca, F. De Crescenzio, M. Fantini, and R. Scotti, "CAD/CAM and rapid prototyped scaffold construction for 
bone regenerative medicine and surgical transfer of virtual planning: a pilot study," Computerized Medical Imaging and Graphics, vol. 33, no. 1, pp. 58-62, 2009.

[83] H. Li, F. Yan, L. Lei, Y. Li, and Y. Xiao, "Application of autologous cryopreserved bone marrow mesenchymal stem cells for periodontal regeneration in dogs," Cells Tissues Organs, vol. 190, no. 2, pp. 94-101, 2009.

[84] M. Jäger, J. Fischer, W. Dohrn et al., "Dexamethasone modulates BMP-2 effects on mesenchymal stem cells in vitro," Journal of Orthopaedic Research, vol. 26, no. 11, pp. 1440-1448, 2008.

[85] G. E. Rooney, C. Moran, S. S. McMahon et al., "Genemodified mesenchymal stem cells express functionally active nerve growth factor on an engineered poly lactic glycolic acid (PLGA) substrate," Tissue Engineering A, vol. 14, no. 5, pp. 681690, 2008.

[86] C. Olivo, J. Alblas, V. Verweij, A.-J. Van Zonneveld, W. J. A. Dhert, and A. C. M. Martens, "In vivo bioluminescence imaging study to monitor ectopic bone formation by luciferase gene marked mesenchymal stem cells," Journal of Orthopaedic Research, vol. 26, no. 7, pp. 901-909, 2008.

[87] J. M. Kanczler, P. J. Ginty, J. J. A. Barry et al., "The effect of mesenchymal populations and vascular endothelial growth factor delivered from biodegradable polymer scaffolds on bone formation," Biomaterials, vol. 29, no. 12, pp. 1892-1900, 2008.

[88] P. Berardinelli, L. Valbonetti, A. Muttini et al., "Role of amniotic fluid mesenchymal cells engineered on $\mathrm{MgHA} /$ collagen-based scaffold allotransplanted on an experimental animal study of sinus augmentation," Clinical Oral Investigations, vol. 17, no. 7, pp. 1661-1675, 2013.

[89] D. K. Bishi, S. Mathapati, J. R. Reddy Venugopal et al., “Transdifferentiation of human mesenchymal stem cells generates functional hepatospheres on poly(L lactic acid)-co-poly(3caprolactone)/collagen nanofibrous scaffolds," Journal of Materials Chemistry B, vol. 1, pp. 3972-3984, 2013.

[90] W. E. Modderman, T. Vrijheid-Lammers, C. W. G. M. Lowik, and P. J. Nijweide, "Removal of hematopoietic cells and macrophages from mouse bone marrow cultures: Isolation of fibroblastlike stromal cells," Experimental Hematology, vol. 22, no. 2, pp. 194-201, 1994.

[91] S. Nadri and M. Soleimani, "Isolation murine mesenchymal stem cells by positive selection," In Vitro Cellular and Developmental Biology-Animal, vol. 43, no. 8-9, pp. 276-282, 2007.

[92] P. Tropel, D. Noël, N. Platet, P. Legrand, A.-L. Benabid, and F. Berger, "Isolation and characterisation of mesenchymal stem cells from adult mouse bone marrow," Experimental Cell Research, vol. 295, no. 2, pp. 395-406, 2004.

[93] C. Wan, Q. He, M. McCaigue, D. Marsh, and G. Li, "Nonadherent cell population of human marrow culture is a complementary source of mesenchymal stem cells (MSCs)," Journal of Orthopaedic Research, vol. 24, no. 1, pp. 21-28, 2006.

[94] S. Nadri and M. Soleimani, "Comparative analysis of mesenchymal stromal cells from murine bone marrow and amniotic fluid," Cytotherapy, vol. 9, no. 8, pp. 729-737, 2007.

[95] M. K. Majumdar, M. A. Thiede, J. D. Mosca, M. Moorman, and S. L. Gerson, "Phenotypic and functional comparison of cultures of marrow-derived mesenchymal stem cells (MSCs) and stromal cells," Journal of Cellular Physiology, vol. 176, no. 1, pp. 57-66, 1998.

[96] D. G. Phinney, "Building a consensus regarding the nature and origin of mesenchymal stem cells," Journal of Cellular Biochemistry, vol. 38, pp. 7-12, 2002.
[97] Y. Mohammadi, H. Mirzadeh, F. E. Moztarzadeh, M. Soleymani, and E. Jabari, "Design and fabrication of biodegradable porous chitosan/gelatin/tricalcium phosphate hybrid scaffolds for tissue engineering," Iranian Journal Of Polymer Science and Technology, vol. 20, no. 89, pp. 297-308, 2007 (Persian).

[98] T. L. Arinzeh, S. J. Peter, M. P. Archambault et al., "Allogeneic mesenchymal stem cells regenerate bone in a critical-sized canine segmental defect," Journal of Bone and Joint SurgerySeries A, vol. 85, no. 10, pp. 1927-1935, 2003.

[99] V. Holan and E. Javorkova, "Mesenchymal stem cells, nanofiber scaffolds and ocular surface reconstruction," Stem Cell Reviews and Reports, vol. 9, no. 5, pp. 609-619, 2013.

[100] W. Zhong, W. Zhang, S. Wang, and J. Qin, "Regulation of fibrochondrogenesis of mesenchymal stem cells in an integrated microfluidic platform embedded with biomimetic nanofibrous scaffolds," PLoS ONE, vol. 8, no. 4, Article ID e61283, 2013.

[101] F. Wang, Y.-C. Zhang, H. Zhou, Y.-C. Guo, and X.-X. Su, "Evaluation of in vitro and in vivo osteogenic differentiation of nano-hydroxyapatite/chitosan/poly(lactide-co-glycolide) scaffolds with human umbilical cord mesenchymal stem cells," Journal of Biomedical Materials Research A, vol. 102, no. 3, pp. 760-768, 2014.

[102] J. L. Ifkovits, H. G. Sundararaghavan, and J. A. Burdick, "Electrospinning fibrous polymer scaffolds for tissue engineering and cell culture," Journal of Visualized Experiments, no. 32, 2009.

[103] S. Liao, R. Murugan, C. K. Chan, and S. Ramakrishna, "Processing nanoengineered scaffolds through electrospinning and mineralization suitable for biomimetic bone tissue engineering," Journal of the Mechanical Behavior of Biomedical Materials, vol. 1, no. 3, pp. 252-260, 2008.

[104] W. J. Li, R. Tuli, C. Okafor et al., "A three-dimensional nanofibrous scaffold for cartilage tissue engineering using human mesenchymal stem cells," Biomaterials, vol. 26, no. 6, pp. 599609, 2005.

[105] S. Kazemnejad, A. Allameh, A. Gharehbaghian, M. Soleimani, N. Amirizadeh, and M. Jazayeri, "Efficient replacing of fetal bovine serum with human platelet releasate during propagation and differentiation of human bone marrow-derived mesenchymal stem cells to functional hepatocytes-like cells," Vox Sanguinis, vol. 95, no. 2, pp. 149-158, 2008.

[106] S. Kazemnejad, A. Allameh, M. Soleimani et al., "Development of a novel three-dimensional biocompatible nanofibrous scaffold for the expansion and hepatogenic differentiation of human bone marrow mesenchymal stem cells," Iranian Journal of Biotechnology, vol. 5, no. 4, pp. 201-211, 2007.

[107] H. Behnia, A. Khojasteh, M. Soleimani et al., "Secondary repair of alveolar clefts using human mesenchymal stem cells," Oral Surgery, Oral Medicine, Oral Pathology, Oral Radiology and Endodontology, vol. 108, no. 2, pp. el-e6, 2009.

[108] J. Justesen, K. Stenderup, and M. S. Kassem, "Mesenchy stem cells. Potential use in cell and gene therapy for bone loss caused by ageing and osteoporosis," Ugeskrift for Laeger, vol. 163, no. 40, pp. 5491-5495, 2001.

[109] M. Battiwalla and P. Hematti, "Mesenchymal stem cells in hematopoietic stem cell transplantation," Cytotherapy, vol. 11, no. 5, pp. 503-515, 2009.

[110] E. M. Horwitz, P. L. Gordon, W. K. K. Koo et al., "Isolated allogeneic bone marrow-derived mesenchymal cells engraft and stimulate growth in children with osteogenesis imperfecta: implications for cell therapy of bone," Proceedings of the National Academy of Sciences of the United States of America, vol. 99, no. 13, pp. 8932-8937, 2002. 
[111] M. Sasaki, O. Honmou, Y. Akiyama, T. Uede, K. Hashi, and J. D. Kocsis, "Transplantation of an acutely isolated bone marrow fraction repairs demyelinated adult rat spinal cord axons," GLIA, vol. 35, no. 1, pp. 26-34, 2001.

[112] C. P. Hofstetter, E. J. Schwarz, D. Hess et al., "Marrow stromal cells form guiding strands in the injured spinal cord and promote recovery," Proceedings of the National Academy of Sciences of the United States of America, vol. 99, no. 4, pp. 21992204, 2002.

[113] J. Schindehütte, W. Paulus, and A. Mansouri, "Stem cell therapy in Parkinson disease," Pharmazie in unserer Zeit, vol. 35, no. 3, pp. 250-254, 2006.

[114] J. Chen, Z. G. Zhang, Y. Li et al., "Intravenous administration of human bone marrow stromal cells induces angiogenesis in the ischemic boundary zone after stroke in rats," Circulation Research, vol. 92, no. 6, pp. 692-699, 2003.

[115] Y. L. Wang, G. Guo, H. F. Chen et al., "Preparation and characterization of polylactide/poly( $\varepsilon$-caprolactone)-poly(ethylene glycol)-poly( $\varepsilon$-caprolactone) hybrid fibers for potential application in bone tissue engineering," International Journal of Nanomedicine, vol. 9, no. 1, pp. 1991-2003, 2014.

[116] L.-X. Lü, X.-F. Zhang, Y.-Y. Wang et al., "Effects of hydroxyapatite-containing composite nanofibers on osteogenesis of mesenchymal stem cells in vitro and bone regeneration in vivo," ACS Applied Materials and Interfaces, vol. 5, no. 2, pp. 319-330, 2013.

[117] M. Du, H. Liang, C. Mou et al., "Regulation of human mesenchymal stem cells differentiation into chondrocytes in extracellular matrix-based hydrogel scaffolds," Colloids and Surfaces B: Biointerfaces, vol. 114, pp. 316-323, 2014.

[118] D. E. Discher, P. Janmey, and Y. L. Wang, "Tissue cells feel and respond to the stiffness of their substrate," Science, vol. 310, no. 5751, pp. 1139-1143, 2005.

[119] P. M. Crapo and Y. Wang, "Physiologic compliance in engineered small-diameter arterial constructs based on an elastomeric substrate," Biomaterials, vol. 31, no. 7, pp. 1626-1635, 2010.

[120] V. L. Sales, G. C. Engelmayr Jr., J. A. Johnson Jr. et al., "Protein precoating of elastomeric tissue-engineering scaffolds increased cellularity, enhanced extracellular matrix protein production, and differentially regulated the phenotypes of circulating endothelial progenitor cells," Circulation, vol.116, no. 11, supplement, pp. I-55-I-63, 2007.

[121] A. Suzuki, Y.-W. Zheng, S. Kaneko et al., "Clonal identification and characterization of self-renewing pluripotent stem cells in the developing liver," Journal of Cell Biology, vol. 156, no. 1, pp. 173-184, 2002.

[122] S. Huang, H. Yam, C. Pang et al., "The expression of human specific proteins in liver tissue of chimeric goats engrafted with human hematopoitic stem cells," Zhonghua yi xue za zhi, vol. 82, no. 13, pp. 894-898, 2002.

[123] M. Kalbacova, A. Broz, J. Kong, and M. Kalbac, "Graphene substrates promote adherence of human osteoblasts and mesenchymal stromal cells," Carbon, vol. 48, no. 15, pp. 4323-4329, 2010.

[124] W. C. Lee, C. H. Y. X. Lim, H. Shi et al., "Origin of enhanced stem cell growth and differentiation on graphene and graphene oxide," ACS Nano, vol. 5, no. 9, pp. 7334-7341, 2011.

[125] L. D. Quarles, D. A. Yohay, L. W. Lever, R. Caton, and R. J. Wenstrup, "Distinct proliferative and differentiated stages of murine MC3T3-E1 cells in culture: an in vitro model of osteoblast development," Journal of Bone and Mineral Research, vol. 7, no. 6, pp. 683-692, 1992.

[126] E. Mooney, P. Dockery, U. Greiser, M. Murphy, and V. Barron, "Carbon nanotubes and mesenchymal stem cells: biocompatibility, proliferation and differentiation," Nano Letters, vol. 8, no. 8, pp. 2137-2143, 2008.

[127] C. Yi, D. Liu, C.-C. Fong, J. Zhang, and M. Yang, "Gold nanoparticles promote osteogenic differentiation of mesenchymal stem cells through p38 MAPK pathway," ACS Nano, vol. 4, no. 11, pp. 6439-6448, 2010.

[128] G. H. Altman, R. L. Horan, I. Martin et al., "Cell differentiation by mechanical stress," The FASEB Journal, vol. 16, no. 2, pp. 270272, 2002.

[129] K. Yamamoto, T. Sokabe, T. Watabe et al., "Fluid shear stress induces differentiation of Flk-1-positive embryonic stem cells into vascular endothelial cells in vitro," The American Journal of Physiology-Heart and Circulatory Physiology, vol. 288, no. 4, pp. H1915-H1924, 2005.

[130] M. J. Dalby, N. Gadegaard, R. Tare et al., "The control of human mesenchymal cell differentiation using nanoscale symmetry and disorder," Nature Materials, vol. 6, no. 12, pp. 997-1003, 2007.

[131] X. Zan, P. Sitasuwan, J. Powell, T. W. Dreher, and Q. Wang, "Polyvalent display of RGD motifs on turnip yellow mosaic virus for enhanced stem cell adhesion and spreading," Acta Biomaterialia, vol. 8, no. 8, pp. 2978-2985, 2012.

[132] K. O’Donoghue and N. M. Fisk, "Fetal stem cells," Best Practice and Research: Clinical Obstetrics and Gynaecology, vol. 18, no. 6, pp. 853-875, 2004.

[133] E. Lagasse, H. Connors, M. Al-Dhalimy et al., "Purified hematopoietic stem cells can differentiate into hepatocytes in vivo," Nature Medicine, vol. 6, no. 11, pp. 1229-1234, 2000.

[134] M. Ochi, Y. Uchio, M. Tobita, and M. Kuriwaka, "Current concepts in tissue engineering technique for repair of cartilage defect," Artificial Organs, vol. 25, no. 3, pp. 172-179, 2001.

[135] R. Tuli, W.-J. Li, and R. S. Tuan, "Current state of cartilage tissue engineering," Arthritis Research and Therapy, vol. 5, no. 5, pp. 235-238, 2003.

[136] R. S. Tuan, G. Boland, and R. Tuli, "Adult mesenchymal stem cells and cell-based tissue engineering," Arthritis Research and Therapy, vol. 5, no. 1, pp. 32-45, 2003.

[137] A. M. De Lise, E. Stringa, W. A. Woodward et al., "Embryonic limb mesenchyme micromass culture as an in vitro model for chondrogenesis and cartilage maturation," in Developmental Biology Protocols, pp. 359-375, Springer, 2000.

[138] B. Johnstone, T. M. Hering, A. I. Caplan, V. M. Goldberg, and J. U. Yoo, "In vitro chondrogenesis of bone marrow-derived mesenchymal progenitor cells," Experimental Cell Research, vol. 238, no. 1, pp. 265-272, 1998.

[139] J. U. Yoo, T. S. Barthel, K. Nishimura et al., "The chondrogenic potential of human bone-marrow-derived mesenchymal progenitor cells," The Journal of Bone and Joint Surgery A, vol. 80, no. 12, pp. 1745-1757, 1998.

[140] A. Muraglia, A. Corsi, M. Riminucci et al., "Formation of a chondro-osseous rudiment in micromass cultures of human bone-marrow stromal cells," Journal of Cell Science, vol. 116, no. 14, pp. 2949-2955, 2003.

[141] J. M. Murphy, K. Dixon, S. Beck, D. Fabian, A. Feldman, and F. Barry, "Reduced chondrogenic and adipogenic activity of mesenchymal stem cells from patients with advanced osteoarthritis," Arthritis and Rheumatism, vol. 46, no. 3, pp. 704-713, 2002. 
[142] M. Radice, P. Brun, R. Cortivo, R. Scapinelli, C. Battaliard, and G. Abatangelo, "Hyaluronan-based biopolymers as delivery vehicles for bone-marrow-derived mesenchymal progenitors," Journal of Biomedical Materials Research, vol. 50, no. 2, pp. 101109, 2000.

[143] U. Nöth, R. Tuli, A. M. Osyczka, K. G. Danielson, and R. S. Tuan, "In vitro engineered cartilage constructs produced by presscoating biodegradable polymer with human mesenchymal stem cells," Tissue Engineering, vol. 8, no. 1, pp. 131-144, 2002.

[144] H. Abukawa, H. Terai, D. Hannouche, J. P. Vacanti, L. B. Kaban, and M. J. Troulis, "Formation of a mandibular condyle in vitro by tissue engineering," Journal of Oral and Maxillofacial Surgery, vol. 61, no. 1, pp. 94-100, 2003.

[145] J. R. Fuchs, D. Hannouche, S. Terada, J. P. Vacanti, and D. O. Fauza, "Fetal tracheal augmentation with cartilage engineered from bone marrow-derived mesenchymal progenitor cells," Journal of Pediatric Surgery, vol. 38, no. 6, pp. 984-987, 2003.

[146] T. Aung, H. Miyoshi, T. Tun, and N. Ohshima, "Chondroinduction of mouse mesenchymal stem cells in three-dimensional highly porous matrix scaffolds," Journal of Biomedical Materials Research, vol. 61, no. 1, pp. 75-82, 2002.

[147] W.-J. Li, C. T. Laurencin, E. J. Caterson, R. S. Tuan, and F. K. Ko, "Electrospun nanofibrous structure: a novel scaffold for tissue engineering," Journal of Biomedical Materials Research, vol. 60, no. 4, pp. 613-621, 2002.

[148] W.-J. Li, K. G. Danielson, P. G. Alexander, and R. S. Tuan, "Biological response of chondrocytes cultured in three-dimensional nanofibrous poly( $\varepsilon$-caprolactone) scaffolds," Journal of Biomedical Materials Research A, vol. 67, no. 4, pp. 1105-1114, 2003.

[149] L. A. Solchaga, K. J. Penick, and J. F. Welter, "Chondrogenic differentiation of bone marrow-derived mesenchymal stem cells: tips and tricks," in Mesenchymal Stem Cell Assays and Applications, vol. 698 of Methods in Molecular Biology, pp. 253278, Springer, Berlin, Germany, 2011.

[150] A. Jemal, F. Bray, M. M. Center, J. Ferlay, E. Ward, and D. Forman, "Global cancer statistics," Cancer Journal for Clinicians, vol. 61, no. 2, pp. 69-90, 2011.

[151] D. M. Parkin, “The global health burden of infection-associated cancers in the year 2002," International Journal of Cancer, vol. 118, no. 12, pp. 3030-3044, 2006.

[152] S. Nishijima, K. Sugaya, M. Miyazato et al., "Restoration of bladder contraction by bone marrow transplantation in rats with underactive bladder," Biomedical Research, vol. 28, no. 5, pp. 275-280, 2007.

[153] J. Liu, J. Huang, T. Lin, C. Zhang, and X. Yin, "Cell-to-cell contact induces human adipose tissue-derived stromal cells to differentiate into urothelium-like cells in vitro," Biochemical and Biophysical Research Communications, vol. 390, no. 3, pp. 931936, 2009.

[154] A. I. Caplan, "Adult mesenchymal stem cells for tissue engineering versus regenerative medicine," Journal of Cellular Physiology, vol. 213, no. 2, pp. 341-347, 2007.

[155] Y. Zhang, E. McNeill, H. Tian et al., "Urine derived cells are a potential source for urological tissue reconstruction," The Journal of Urology, vol. 180, no. 5, pp. 2226-2233, 2008.

[156] L. L. Woo, S. T. Tanaka, G. Anumanthan et al., "Mesenchymal stem cell recruitment and improved bladder function after bladder outlet obstruction: preliminary data," Journal of Urology, vol. 185, no. 3, pp. 1132-1138, 2011.

[157] P. de Coppi, A. Callegari, A. Chiavegato et al., "Amniotic fluid and bone marrow derived mesenchymal stem cells can be converted to smooth muscle cells in the cryo-injured rat bladder and prevent compensatory hypertrophy of surviving smooth muscle cells," The Journal of Urology, vol. 177, no. 1, pp. 369-376, 2007.

[158] S. T. Tanaka, M. Martinez-Ferrer, J. H. Makari et al., "Recruitment of bone marrow derived cells to the bladder after bladder outlet obstruction," The Journal of Urology, vol. 182, no. 4, pp. 1769-1774, 2009.

[159] S. Y. Chung, N. P. Krivorov, V. Rausei et al., "Bladder reconstitution with bone marrow derived stem cells seeded on small intestinal submucosa improves morphological and molecular composition," Journal of Urology, vol. 174, no. 1, pp. 353-359, 2005.

[160] D. Frimberger, N. Morales, M. Shamblott, J. D. Gearhart, J. P. Gearhart, and Y. Lakshmanan, "Human embryoid bodyderived stem cells in bladder regeneration using rodent model," Urology, vol. 65, no. 4, pp. 827-832, 2005.

[161] G. Anumanthan, J. H. Makari, L. Honea et al., "Directed differentiation of bone marrow derived mesenchymal stem cells into bladder urothelium," The Journal of Urology, vol. 180, no. 4, pp. 1778-1783, 2008.

[162] A. K. Sharma, P. V. Hota, D. J. Matoka et al., "Urinary bladder smooth muscle regeneration utilizing bone marrow derived mesenchymal stem cell seeded elastomeric poly(1,8-octanediolco-citrate) based thin films," Biomaterials, vol. 31, no. 24, pp. 6207-6217, 2010.

[163] G. S. Jack, R. Zhang, M. Lee, Y. Xu, B. M. Wu, and L. V. Rodríguez, "Urinary bladder smooth muscle engineered from adipose stem cells and a three dimensional synthetic composite," Biomaterials, vol. 30, no. 19, pp. 3259-3270, 2009.

[164] P. X. Ma, "Biomimetic materials for tissue engineering," Advanced Drug Delivery Reviews, vol. 60, no. 2, pp. 184-198, 2008.

[165] S. M. Kunisaki, M. Armant, G. S. Kao, K. Stevenson, H. Kim, and D. O. Fauza, "Tissue engineering from human mesenchymal amniocytes: a prelude to clinical trials," Journal of Pediatric Surgery, vol. 42, no. 6, pp. 974-980, 2007.

[166] S. M. Kunisaki, J. R. Fuchs, A. Kaviani et al., "Diaphragmatic repair through fetal tissue engineering: a comparison between mesenchymal amniocyte- and myoblast-based constructs," Journal of Pediatric Surgery, vol. 41, no. 1, pp. 34-39, 2006.

[167] S. M. Kunisaki, D. A. Freedman, and D. O. Fauza, "Fetal tracheal reconstruction with cartilaginous grafts engineered from mesenchymal amniocytes," Journal of Pediatric Surgery, vol. 41, no. 4, pp. 675-682, 2006.

[168] C. F. Andrade, A. P. Wong, T. K. Waddell, S. Keshavjee, and M. Liu, "Cell-based tissue engineering for lung regeneration," The American Journal of Physiology: Lung Cellular and Molecular Physiology, vol. 292, no. 2, pp. L510-L518, 2007.

[169] M. J. Mondrinos, S. Koutzaki, E. Jiwanmall et al., "Engineering three-dimensional pulmonary tissue constructs," Tissue Engineering, vol. 12, no. 4, pp. 717-728, 2006.

[170] M. J. Mondrinos, S. Koutzaki, P. I. Lelkes, and C. M. Finck, "A tissue-engineered model of fetal distal lung tissue," The American Journal of Physiology - Lung Cellular and Molecular Physiology, vol. 293, no. 3, pp. L639-L650, 2007.

[171] J. Cortiella, J. E. Nichols, K. Kojima et al., "Tissue-engineered lung: an in vivo and in vitro comparison of polyglycolic acid and pluronic F-127 hydrogel/somatic lung progenitor cell constructs to support tissue growth," Tissue Engineering, vol. 12, no. 5, pp. 1213-1225, 2006. 
[172] N. Shigemura, M. Okumura, S. Mizuno, Y. Imanishi, T. Nakamura, and Y. Sawa, "Autologous transplantation of adipose tissue-derived stromal cells ameliorates pulmonary emphysema," American Journal of Transplantation, vol. 6, no. 11, pp. 2592-2600, 2006.

[173] S. Baiguera, P. Jungebluth, A. Burns et al., "Tissue engineered human tracheas for in vivo implantation," Biomaterials, vol. 31, no. 34, pp. 8931-8938, 2010.

[174] P. Macchiarini, P. Jungebluth, T. Go et al., "Clinical transplantation of a tissue-engineered airway," The Lancet, vol. 372, no. 9655, pp. 2023-2030, 2008.

[175] F. L. Gray, C. G. Turner, A. Ahmed, C. E. Calvert, D. Zurakowski, and D. O. Fauza, "Prenatal tracheal reconstruction with a hybrid amniotic mesenchymal stem cells-engineered construct derived from decellularized airway," Journal of Pediatric Surgery, vol. 47, no. 6, pp. 1072-1078, 2012.

[176] T. Nakamura, T. Sato, M. Araki et al., "In situ tissue engineering for tracheal reconstruction using a luminar remodeling type of artificial trachea," The Journal of Thoracic and Cardiovascular Surgery, vol. 138, no. 4, pp. 811-819, 2009.

[177] T. Suzuki, K. Kobayashi, Y. Tada et al., "Regeneration of the trachea using a bioengineered scaffold with adipose-derived stem cells," The Annals of Otology, Rhinology and Laryngology, vol. 117, no. 6, pp. 453-463, 2008. 


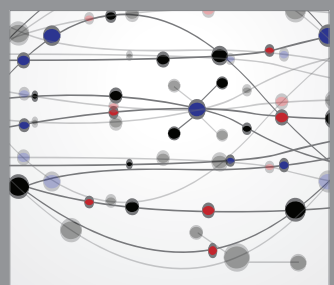

The Scientific World Journal
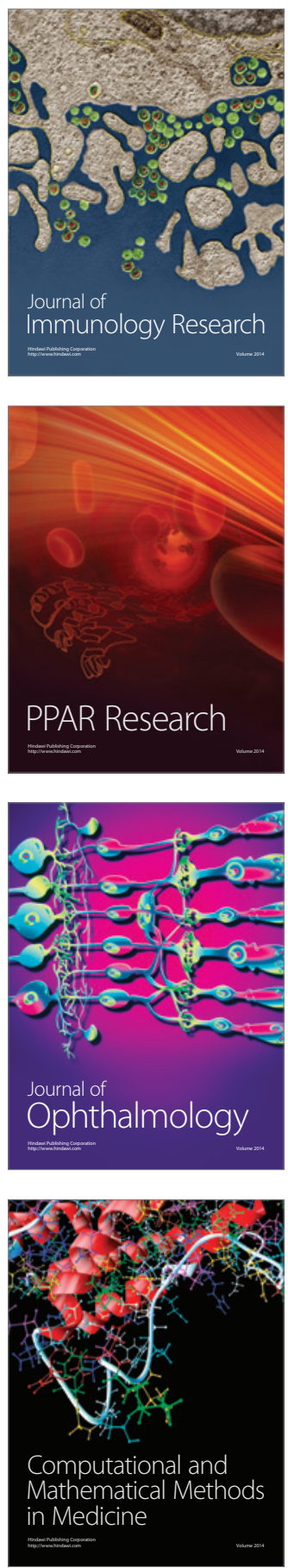

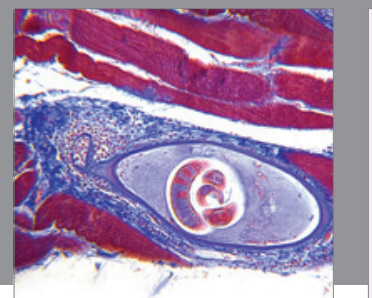

Gastroenterology

Research and Practice
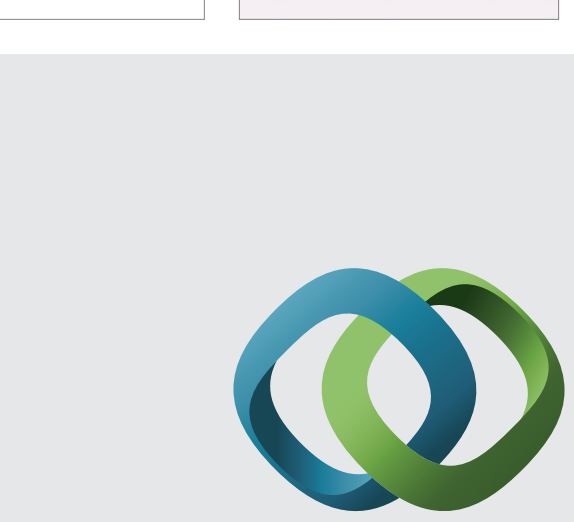

\section{Hindawi}

Submit your manuscripts at

http://www.hindawi.com
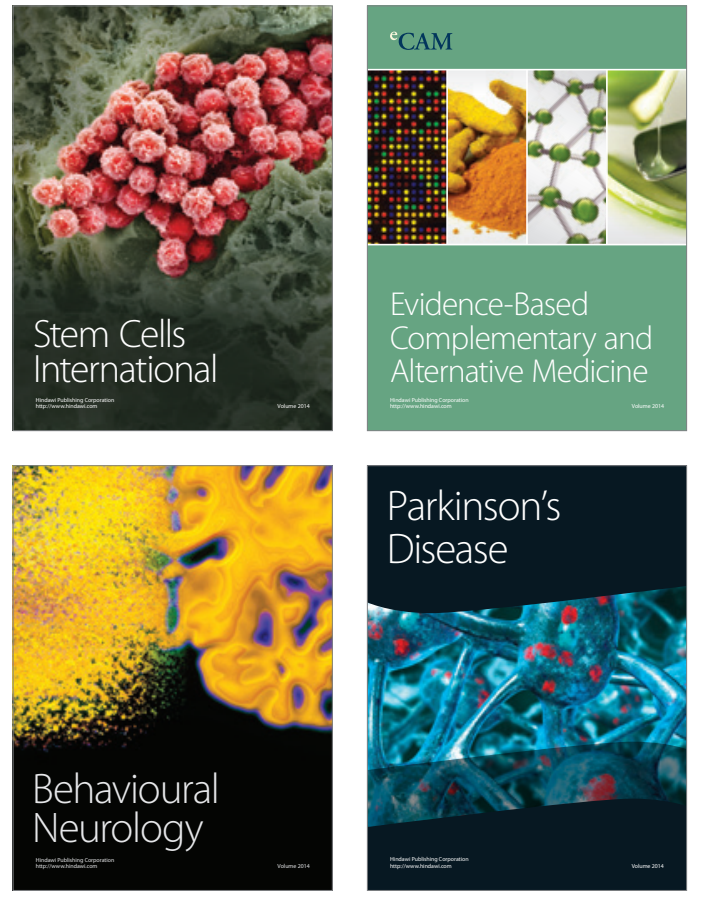
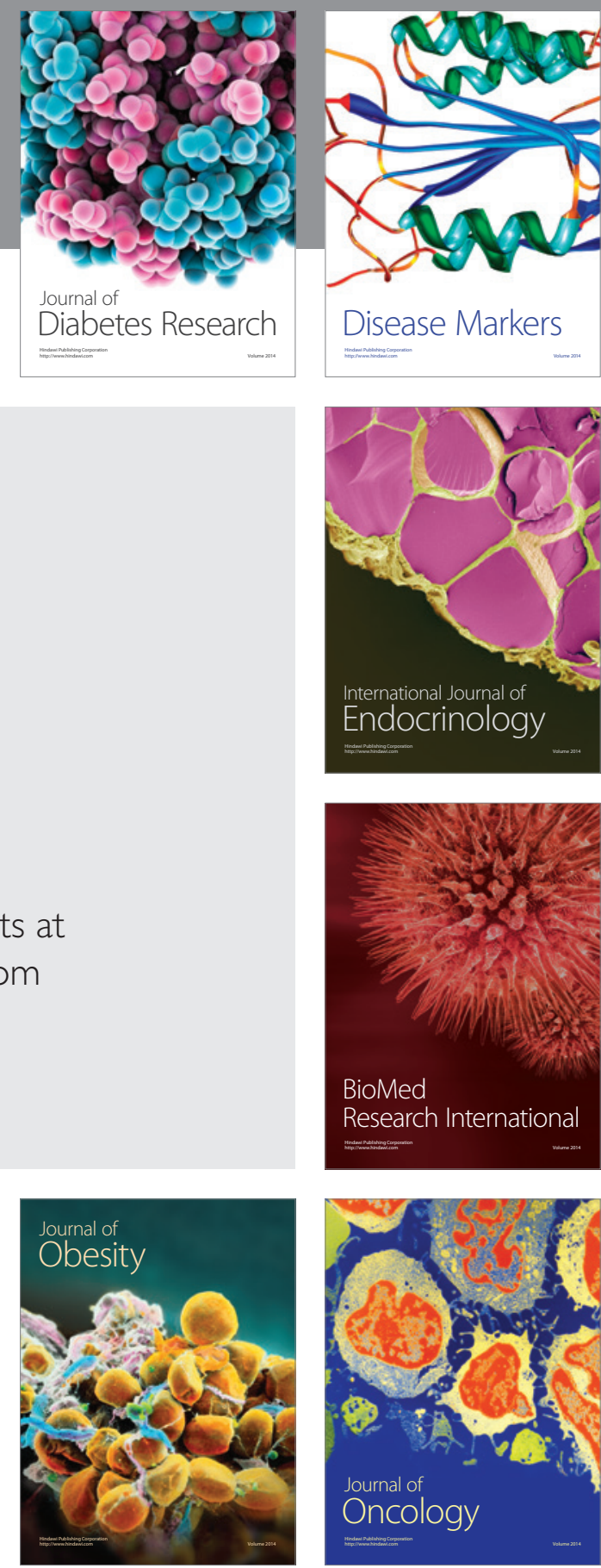

Disease Markers
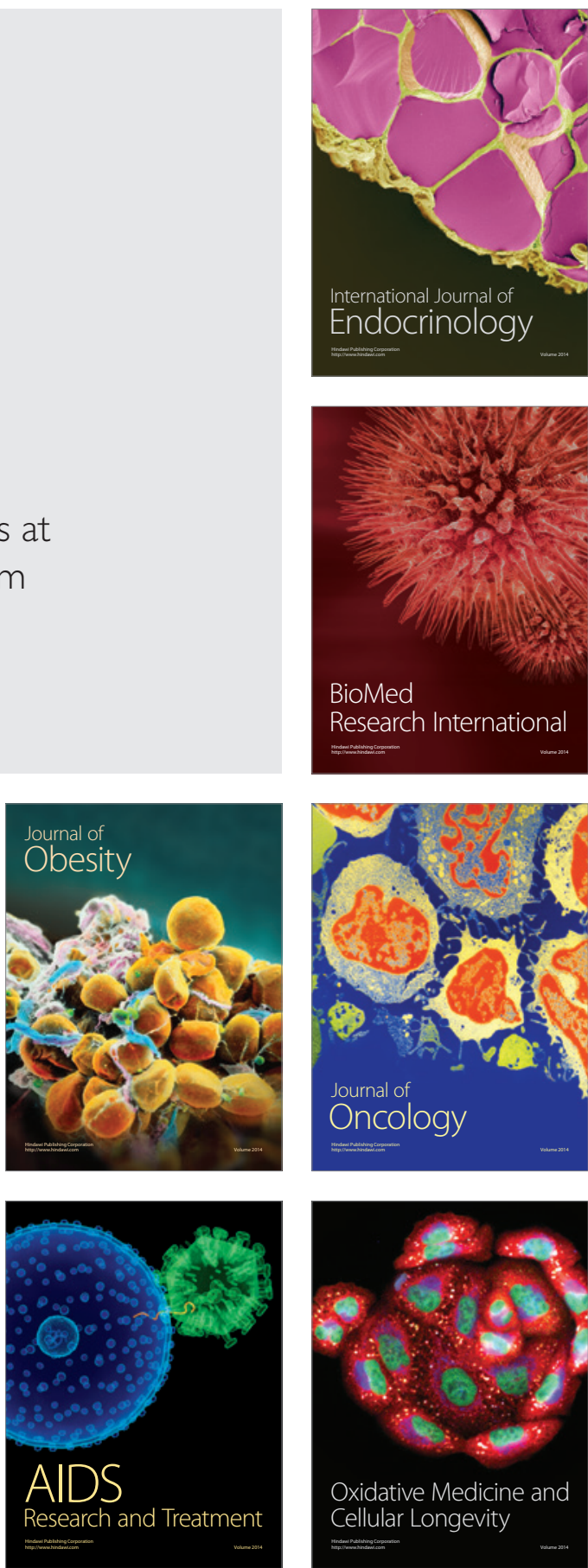